\title{
Exploring recontextualization of didactic ability and vocational teacher students' professional learning through video analysis
}

\author{
Daniel Alvunger, Viktoria Grahn Johansson \\ Linnæus University, Sweden (daniel.alvunger@lnu.se)
}

\begin{abstract}
This article explores how vocational teacher education (VTE) students experience professional learning through the use of video analysis, their reflection among peers and their meaning-making of the 'didactic ability' concept during the beginning of their education. The empirical data consists of an online survey and semi-structured interviews with five vocational teacher education students. Bernstein's concept of 'pedagogic discourse' and a conceptual framework of recontextualisation in vocational education and training developed by Evans, Guile and Harris guide the research. The findings strongly support observations from previous research that emphasise that the use of video promotes and supports teacher students' professional growth. The VTE students develop a new understanding of how to organise content and to analytically handle the relationship between theoretical aspects and professional action. The emerging meanings of didactic ability are a new discursive understanding of work-knowledge and the teaching content, as well as a strategic structuring of the content for sense-making, transcending the theory and practice divide through visual artefacts and practical tasks and the ability to use different teaching strategies. Language, actions, content and meanings in terms of workplace codes tend to 'move' and to be recontextualised from the school's pedagogic discourse.
\end{abstract}

Keywords: vocational teacher education, students' professional learning, videoanalysis, recontexualisation, pedagogic discourse 


\section{Introduction}

We have worked as lecturers in vocational teacher education (VTE) for over 10 years. In relation to introducing a new course assignment that includes video recording and analysis of a teaching sequence, we became curious regarding the impact video analysis and reflection might have for VTE students' professional learning. In brief, the assignment instructed the students to construct and videorecord an individual presentation that focused on the history of learning and education within their vocational field, as related to important changes and reforms in the $20^{\text {th }}$-century school system (see more in detail below). The assignment builds on two aims from the programme syllabus. They concern what in Swedish is called knowledge of teaching and learning, instructional skills and planning and evaluation regarding the (vocational) subject, which we here have translated to 'didactic ability'. As lecturers in the course, we were interested in how the students conceive and make meaning from didactic ability, particularly since this was in the beginning of their education. Besides a personal interest in learning more about the students' experiences, we also became aware that few research studies have explicitly targeted the use of video analysis for advancing students' professional learning in VTE.

Over the recent decades, the quality of teachers and teacher education has been a high-stakes issue in the global education policy agenda (Alvunger \& Wahlström, 2017; Cochran-Smith \& Villegas, 2015; Robertson \& Dale, 2015). In the context of vocational education and training (VET) and VTE, there is a strong belief that standardised qualification frameworks and the restructuring of VET systems will decrease unemployment, develop human capital and promote economic growth (Boutsiouki, 2014; Rauner \& Maclean, 2008; Wallenborn, 2010). Debates regarding VTE reflect specific notions about teacher professionalism and qualifications for vocational teacher recruitment (Moreno Herrera, 2016), as well as the relationship between school practice and academic research (Alvunger \& Adolfsson, 2016; Cochran-Smith \& Lytle, 1999; Darling-Hammond, 2006). VTE models deal with this relationship in different ways. In Germany and Norway, VTE students receive a master's degree or bachelor's degree with an integration between vocational disciplinary studies and vocational didactics. The VTE in the U.S. and Denmark consists of teacher training, instruction and methodology 'on top of' the required vocational knowledge and experience (Grollmann, 2008). In England and Scotland, a neo-liberal policy discourse that stresses a shorter and more efficient education based on teacher preparation in the classroom, with a focus on instrumental-technical dimensions, has reshaped VTE (Avis, Canning, Fisher, Morgan-Klein \& Simmons, 2012).

Teachers must know how students learn and how to teach, to be familiar with the aims and content in the curriculum and to have the knowledge and skills within their particular field or subject (Darling-Hammond, 2008; Papier, 2011). In 
terms of VET teachers and VTE students, there are some specific aspects that need to be addressed in terms of didactic ability and professional learning. Köpsén and Andersson (2015) argue that VET teachers can be seen as carriers of a 'dual professionalism', meaning they have knowledge and experience from work-life and the community of practice in schools. The knowledge-base differs from teachers in general subjects in terms of the context-bound, action-oriented and experiencebased character of vocational knowledge (Kemmis \& Green, 2013; Papier, 2011; Wheelahan, 2015) and the connection to vocational identity (Köpsén, 2014). VET teachers and VTE students face a challenge regarding how their knowledge and skills should be transferred because tacit dimensions of knowledge are difficult to make explicit (Alvunger \& Adolfsson, 2016). Through their teacher education, the VTE students move into the discourse of the teaching profession. They have to reflect upon how theoretical knowledge underpinning their occupational field as well as practical and contextual elements of workplace knowledge can be framed within teaching situations. It is this didactic reflection and the emerging meanings of didactic ability - reflected in the assignment with the use of video that will be in focus in this article.

The article explores how VTE students experience professional learning through the use of video analysis, their reflection among peers and their meaning-making of the didactic ability concept during the beginning of their education. What qualities do the students ascribe video analysis for facilitating and supporting their professional learning? How do they look upon the use of video for teaching in their vocational subjects? What notions of didactic ability emerge from the students' analyses of, and reflections on, the video sequences? Bernstein's (2000) concept of 'pedagogic discourse' and a conceptual framework of recontextualisation in VET developed by Evans, Guile and Harris $(2009,2010)$ will guide the analysis of the different meanings that emerge.

\section{Previous research on video use in teacher education}

The use of videos for forwarding and supporting teacher students' professional learning and teachers' professional development (Marsh \& Mitchell, 2014; Tripp \& Rich, 2012) is an expansive research field. Even if VTE is under-represented in this field, there is much to learn from evidence in previous research. The first observation made from the research is a general recognition that the use of video in teacher education offers ways for teacher students to bridge the gap between theory and practice in terms of applying knowledge acquired at university for analysing and guiding their teaching practice (Barnhart \& van Es, 2015; Blomberg, Renkl, Shering, Borko \& Seidl, 2013; Charalambous, Philippou \& Olympiou, 2018; Gelfuso \& Dennis, 2017). The most obvious advantages with video are capturing the multi-layered, diverse context and having the possibility to discuss tacit dimensions, such as good judgment embedded in practice. As Marsh and Mitchell (2014) describe it: 
video presents a uniquely effective means of didactic demonstration since it enables the illustration of complex sets of circumstances which may be resistant to verbal representation and which in any event may be more clearly and powerfully demonstrated by 'real people in real situations' than they may be by the abstraction of a teacher educator at one remove from the classroom activity. (Marsh \& Mitchell, 2014, p. 405)

However, the facilitation through video must be integrated within the rationale and structure of the education and founded on research-based knowledge (Blomberg et al., 2013). Other contextual factors for support are important, and the use of video as such does not exclusively shape students' professional learning (Gaudin, Flandin, Ria \& Chaliès, 2014). This corresponds with studies that underline the importance of VTE assignments being grounded on practical tasks, the significance of a relationship between theory and practice and the possibilities for VTE students to apply various strategies (Sylte \& Jahanlu, 2017). Accordingly, teaching based on active student participation promotes motivation and supports the VTE students' understanding of theoretical concepts (Syverstad \& Nymark, 2016).

A second observation from previous research is that the use of video analysis sharpens and directs the teacher students' attention and sensibility towards how students react and in what ways their teaching practice can be improved (Alsawaie \& Alghazo, 2010; Barnhart \& van Es, 2015; Tripp \& Rich, 2012). In a comparison between two teacher student cohorts, Barnhart and van Es (2015) found that the cohort of teacher students using video analysis as a basis for professional learning were more inclined to reflect on and question their actions in the classroom than those who had not. Correspondingly, video-based courses seem to make teacher students more aware of how critical examination of their instruction can help improve and make teaching more effective (Stürmer, Könings \& Seidel, 2012). Thus, evidence from research suggests that teacher students and teachers develop instructional skills and extend their teaching repertoires. However, this is not the same as saying that teacher students learn in a similar way or follow unilinear learning trajectories (Charalambous et al., 2018). Furthermore, video analysis and discussion does not automatically lead to reflection on action. As Calandra, Gurvitch and Lund (2008) have shown, teacher students must be supported and provided with tools for reflection and discussion; otherwise, there is an apparent risk that students mainly address instructional-technical and trivial aspects of classroom practice (Calandra et al., 2008).

Finally, a third observation we make from previous research is the importance of facilitating and fostering relational and discursive aspects when using video analysis for professional learning. A vital dimension is that teacher students acquire concepts from the world of practice and become a part of the teaching profession's discourse (Marsh \& Mitchell, 2014). Gelfuso and Dennis (2017) argued there is great potential in supporting teacher student learning through video dur- 
ing field practice together with the triad model of teacher student, university supervisor and in-service supervisor. In a similar way, professional learning communities for exchanging ideas and reflecting on skills serve as significant arenas for teachers to develop analytical skills and for scaffolding their learning (Borko, Jacobs, Eitelorg \& Pittman, 2008; Gaudin et al., 2014). For example, studies on the professional development of VET teachers show that there must be an awareness that contextual and historical factors shape the possibilities for how new methods and tools may be introduced and made an integral part of VET teachers' everyday practice (Bound, 2011). Visual artefacts like pictures and video help VET teachers visualise and conceptualise implicit and action-based knowledge. These 'inscription devices' become vehicles for transferring knowledge between the work context and the school context (Broad, 2016). In a similar way, Nore (2015) argues that e-portfolios become boundary objects in what is referred to as 'hybrid learning-arenas'. The emergence of hybrid learning-arenas and digital tools as boundary objects - together with the significance of being attentive to contextual conditions - are interesting observations for understanding different aspects of how VTE students experience their professional learning through the use of video analysis, as well as the meanings that VTE students attribute to didactic ability.

\section{Background and case study}

VTE in Sweden is part of the higher education system and admittance requires relevant vocational knowledge and experience and special qualifications. The qualifications are validated to match the vocational subjects within the different VET programmes in upper secondary school. Teacher education programmes in Sweden must include one year of full-time study in the 'educational science core' (60 ECTS) and half a year of teacher training placement (30 ECTS). Therefore, a VTE degree is 90 ECTS. The educational science core consists of sub-areas, such as development, learning and special education; the school system, history, fundamental values and social conditions; curriculum theory and didactics; assessment and grading; social relations, conflict management and leadership; theory of science and research methodology; and evaluation and development work (Official Report, 2008).

The VTE programme used as a case in this study is organised as part-time studies. Most of the education is distance-based, and the students visit the university for about three days on approximately six occasions per academic year. Each autumn, about 60 students are admitted to the VTE programme. The student cohort is diverse:

- About 20-25\% of the teacher students have had no previous teaching experience. 
- There are students who have experienced studies in higher education and those who have not. Thus, students' attitudes towards studying may differ significantly.

- Students may enrol on a voluntary basis or feel compelled to do so because they need a degree for a permanent position.

- The students will be qualified to teach different vocational subjects and courses due to their various vocational backgrounds, cultures and identities. It creates a dynamic within the relationships and structures of the student groups.

The case for the present study consists of an assignment in the first course of the programme. The assignment is based on the following aims from the programme syllabus, and the student should be able to:

- apply such didactics and subject didactics required for teaching and learning within the subject or the subjects that the education is for and for the exercise of the profession in general;

- independently and together with others, plan, perform, evaluate and develop teaching and education in general to best stimulate each student's learning and development.

In the course syllabus, the aims are directed towards describing the schooling system in a historical and curriculum theoretical perspective with particular focus on VET. The students should be able to show communicative ability and to reason about different kinds of digital forms of representation in the school. The assignment for examining the students from these aims is designed in two parts, and the second part is this study's focus. Part one is a written assignment on the different changes within VET as part of the schooling system from approximately 1920 until today. The assignment's content is course literature, lectures, complementary materials that the students can find (such as books and stories) and an interview with someone who has had extensive experience working within their field and can describe what the education looked like years ago. In part two of the assignment, the VTE students video-record an individual presentation for a maximum of eight minutes that focuses on the historical development of learning and education within their vocational field while relating to important changes in the school system. The students are presented the following scenario:

You are working as a VET teacher in an upper secondary school. During a lesson, a student asks you how it was when you learned your vocation, what the education looked like and how knowledge and skills have developed within your vocation. The other students become curious and ask about who the teacher was and how the teaching and workplace learning parts were shaped. You promise that you will get back to this during the next lesson. (Our translation, authors). 
The students are given free hand to design their presentations, which means they can choose the site for their recording and what resources they want to use for the presentation. When the video is complete, it must be uploaded on the learning management system and shared with the other students in the group. The VTE students look at each other's video-recordings and write a personal reflection based on them. At the end of the semester, the students discuss their reflections and share their experiences during a seminar. The seminar also serves as a preparation for their teacher training placement in the following semester.

\section{Theoretical and analytical framework}

Singh, Thomas and Harris (2013) mean that a programme syllabus is a policy document and a pedagogic 'text' produced within a certain pedagogic discourse. When a policy document is moved into the pedagogical field of recontextualization, for instance within the context of a university's VTE programme, it becomes subject to the recontextualising rules and the 'de-coding' and 're-coding' process of pedagogic discourse. The recontextualising rules concern the translation and justification of the values of society, power relations, the transmission of knowledge - the 'how' of teaching - and the knowledge and skills that are to be (re)produced: the 'what' and the content of teaching (Bernstein, 2000). Thus, recontextualisation is a process of 'meaning-making' and of recasting concepts that generates new meanings in pedagogic practice on different levels, from elaborated policy codes to codes of classroom conversations (Bernstein, 2000; cf. Singh et al., 2013).

The pedagogic discourse of VTE/VET is complex because it includes different practices, logics and codes from separate fields. Based on Bernstein's recontextualising rules (2000), Evans et al. $(2009,2010)$ have developed a conceptual framework - 'putting knowledge to work' - for the study of vocational and professional educations (Evans et al., 2009, 2010). They identify four types of recontextualisation in education, and their internal relationship is illustrated in the following figure: 


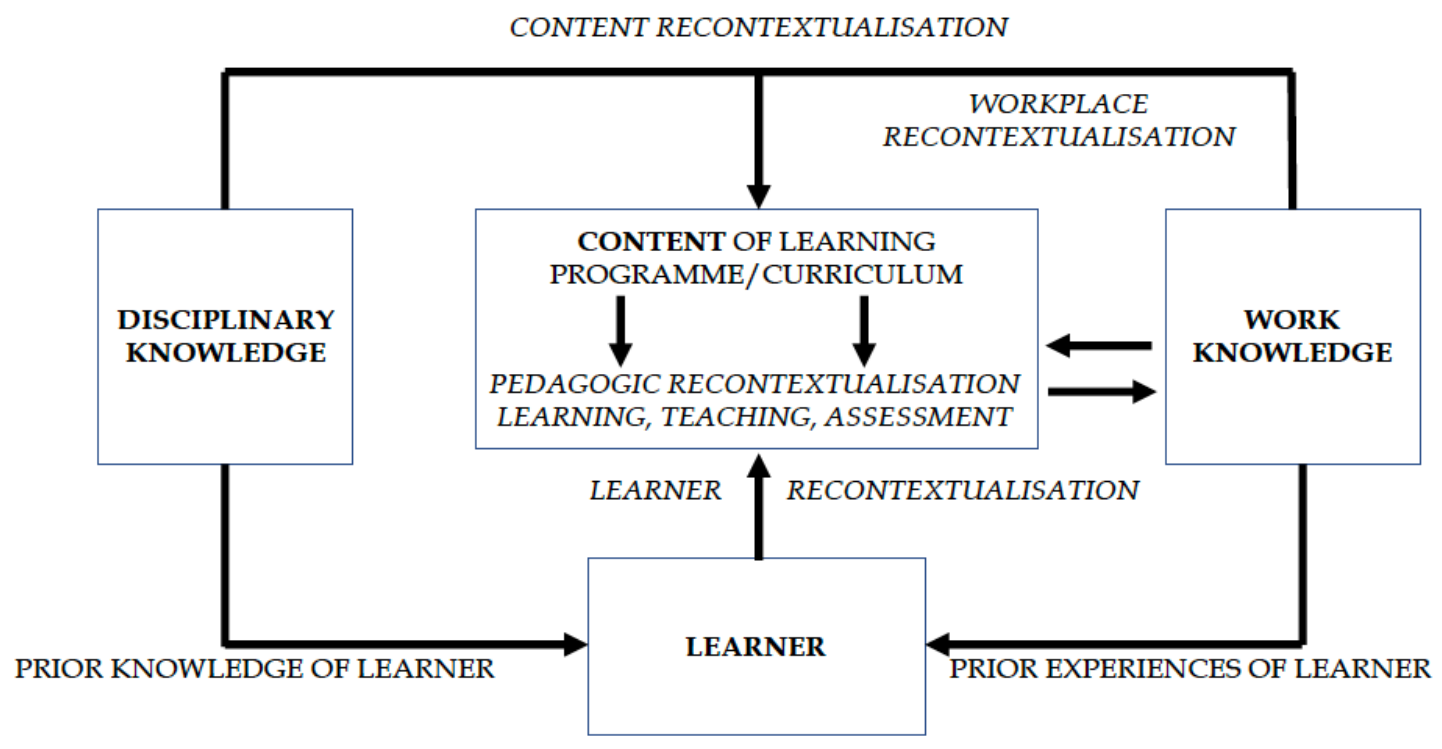

Figure 1. 'Putting Knowledge to Work', based on Evans et al., 2010, p. 247.

'Content recontextualisation' refers to the selection of codified disciplinary knowledge and work knowledge and how it is framed in the programme design environment through the curriculum (Evans et al., 2009, 2010). In this respect, pedagogic discourse is de-coded and re-coded in a pedagogic text - e.g. a course syllabus. The transformation of content into teaching and learning activities is a process of de-coding and re-coding referred to as 'pedagogic recontextualisation'. As Evans et al. (2009, 2010) argue, pedagogic recontextualisation encompasses the organisation, sequencing and structuring of the curriculum into teaching, learning and assessment activities. According to this, discourses from the workplace context and codes also influence the pedagogic discourse within a programme environment, creating 'workplace recontextualisation'. For instance, didactic ability might be understood and interpreted quite differently than in the school context because the workplace is operated by a logic that is about vocational socialisation and acquiring a vocational/professional identity.

VTE students enter the education programme with prior knowledge and experience from previous studies and/or work. In the first case, knowledge is acquired through studies in vocational subjects or disciplinary subjects, e.g. medicine, pedagogy, technology. In the latter case, the VTE students have years of experience from working within their particular occupation. Both of these aspects are important for the students' agency as learners. The process where learners make meaning out of their education in terms of the different recontexualisation processes is what Evans et al. $(2009,2010)$ refer to as 'learner recontextualisation'. This is the forming of a vocational teacher identity. 
Bernstein (2000) argues that pedagogical identity is based on a collective foundation formed by the knowledge content and the distribution of knowledge in a certain education. This corresponds to learner recontextualisation in the sense that the learner is an agent in the creation of pedagogic text and a (re)producer of pedagogic discourse, and this process shapes a sense of belonging, self-understanding and recognition. We are interested in how the VTE students' previous knowledge and experiences influence the teaching content's transformation and the didactic ability notions that emerge in their analysis and reflection on the video sequence. The interplay between the different types of recontextualisation is of course important. For our study, the analysis of the use of video for professional learning and meaning-making for didactic ability will focus on learner recontextualisation.

\section{Research design, methods and empirical data}

The so-called theory-based evaluation, which offers methodological and analytical tools for integrating change-theory and process-analysis, inspired this study (Sundberg, 2017; Wahlström \& Sundberg, 2015). While the aim in traditional evaluations is to control results, to check or to study cause and effect, theorybased evaluation aims to provide analytical models for change-oriented analyses that go beyond conventional product-related evaluations. By using the theoretical concept of 'recontextualisation' presented above, this study explores the questions of 'how' and 'why' certain results and processes occur (Sundberg, 2017; Wahlström \& Sundberg, 2015).

A theory-based evaluation may encompass various evaluation methods, and the present study has chosen a mixed-method design. Through a combination of quantitative and qualitative methods, complementary types of data could be sampled (Creswell, 2010; Creswell \& Plano Clark, 2007), which provided rich material for analysing how the VTE students experienced the assignment and how they make meaning of didactic ability. In line with this design, the empirical data was collected and analysed in two steps.

In the first step, the students were asked specific questions concerning the assignment 'My vocational education in a historical perspective - part 2' as part of a regular online survey at the end of the course. The survey was distributed to 53 students, and the response rate was $60 \%$. The students were asked to evaluate the extent to which the assignment had relevance regarding 'the development of your didactic ability' along the following scale: 'to a very large extent', 'to a pretty large extent', 'to a small extent', 'not at all'. In addition to the questions, the students could describe in free text how they experienced the assignment (voluntary). To provide a deeper understanding of how the students regarded the importance of video analysis for their professional learning and of the didactic ability notions that emerged from the students' recontextualisation of the assign- 
ment, the second step was sampling qualitative data through semi-structured interviews with five students. The questions were open and concerned how the students would reason about didactic ability, for instance 'In what ways did your didactic ability develop through the assignment?' Other questions were: 'How do you experience the use of video analysis for developing teaching and supporting your professional learning?'; 'In what ways did the presentation and videorecording shape your understanding of the content that was presented?'; 'How did you produce a recording that your fellow students and the university teachers would watch?'; 'What did you learn from watching and reflecting on your peers' video-recordings?'; 'What significance do you ascribe the seminar at the end of the semester?' Follow-up questions were asked during the interview for clarifications. The qualitative data from the interviews added important information for understanding how the students looked upon the use of video for teaching their vocational subjects.

Because of the student group's heterogeneous character, different students were selected to balance between male (3) and female (2) students and between students with previous teaching experience (3) and those who had none (2). Due to geographical reasons, the interviews were made by phone, and the students were given the interview questions in advance. Each interview lasted approximately an hour and was recorded for transcription purposes. Notes were also taken during the interviews to mark particular observations relating to how students made meaning of didactic ability in the use and analysis of their video recordings. This was helpful in the transcription process and for analysing data.

\section{Findings}

In the survey, $75 \%$ of the students claimed the assignment had helped them develop their didactic ability 'to a very large extent/fairly large extent', while about $20 \%$ answered 'to a small extent'. This indicates that the analysis of, and reflection upon, the video sequence, together with the peer discussions, had an impact on the students in terms of advancing and scaffolding their learning and professional growth. There were also some technical issues, such as the challenge to record their presentation and to publish it on the learning management platform. The interviews gave a deeper understanding of how the students experienced the use of video, what aspects they believed had helped them to develop their professional learning and the meanings attributed to didactic ability.

\section{Making meaning of teaching and didactic ability}

An aspect shared by the students was that their understanding of vocational education and training history - including their own personal history of learning the vocation - changed when they had to transform their previous knowledge and experience together with the content into a teaching sequence. The content 
had to be comprehensible for the VET students, and this challenged the VTE students to approach the content in the course literature from a personal point of view when they had to gather information from, for instance, interviews with older workers or work descriptions and relate it to central educational reforms. This suggests that knowledge rooted in workplace codes were reshaped according to the pedagogic discourse of schooling. They also had to 'translate' vocational concepts to fit the specific teaching context. This made them reflect on the significance of a 'vocational language' as part of the VET teacher's didactic ability. A VTE student specialised in the Business and Administration programme described this in the following way:

I think it is important to use a vocational terminology and words, so the students learn how to talk with their teacher and vice versa, for me to be able to talk to the students. You have a certain language when you work, you know. Then you cannot use it with the customers while you are working, but an internal language is good to have $[\ldots]$ and that the students actually know what the words mean. (Student interview 3)

An important aspect in the quote is the emphasis that VET students must be granted access to a knowledge base via the vocation's specific language. The example shows that notion that vocational knowledge and workplace code must be configured within school discourse underpins the conception of didactic ability in the pedagogic discourse emerging from the ability for the VTE students' is helping VET students' descriptions. Thus, an essential aspect of didactic ability is helping the VET students make sense of concepts and 'codes' from the world of work as a process of socialisation in the vocation.

A related aspect to the communication of vocational knowledge is in what ways the content is presented. During several occasions in the interviews, the VTE students mentioned how they had to reflect on and critically examine their own performance in terms of disposition, gestures, the sound of their voice and how they positioned themselves in the classroom or at the recording site. One of the meanings of didactic ability that we identify in the analysis is that it includes knowledge and skills to structure the content and to help the students make sense of the content through a logical and coherent order. The VTE students argue that preparations are crucial: 'You prepare a lot, you understand the significance of making the right arrangements, that you must be well prepared' (Student interview 1). This notion of preparedness is particularly evident in the answers from VTE students who lacked teaching experience, while those students who work as teachers indicate that watching different teaching sequences made them aware of different teaching strategies to use. The VTE students without prior teaching experience also generally pointed at how the video analysis helped prepare them for their teacher training placement, or as a student explained in the following quote: 


\begin{abstract}
Since I came here, to the vocational teacher education, I can understand, because it is a lot of such technology that is used at the adult education centre [where the student was doing his/her teacher training placement] and you get like an insight in how you are working, especially for us who haven't worked and currently don't work as teachers. It gives quite a, yes, what should I say, a kind of revelation that you can use it [digital media] in such a way. (Student interview 4)
\end{abstract}

The quote above reflects the notion that the use of digital media is a sign of being 'modern', and a progressive teacher knows how to renew and reshape teaching. In this respect, it is possible to identify a pedagogic discourse with an understanding of didactic ability as mastering repertoires for teaching or being able to use a 'toolbox' of strategies and methods. This includes creating representations of content through other formats that might be easier for the VET students to comprehend. For instance, the VTE students consider pictures and videos as suitable formats for the students in upper secondary school, particularly when it concerns dealing with the context-bound, action-oriented and experience-based character of vocational knowledge: 'It becomes much easier, I think. Later when you did it [the presentation] with a lot of images, with PowerPoint, then it becomes really clear and comprehensible and you try to keep it that way' (Student interview 1). In this respect, the use of video contributed to help the VTE students identify different strategies for widening their teaching repertoires.

Related to the idea of mastering various strategies for teaching as an embedded quality of didactic ability is the notion that the use of video and images provide the VET teacher with a kind of language that makes it possible to transcend the theory and practice dichotomy. The use of video for teaching in their vocational subjects is particularly important because it offers a new kind of interactivity and ways for VET students to engage in the (re)production and meaningmaking of vocational subject-matter. To be able to show and explain concepts and procedures from a holistic point of view is a substantial element that appears in the pedagogic discourse of the VTE students.

Through recordings of teaching vocational subjects in workplace environments, the teacher is able to use both gestures and pictures. The VTE students claim that it is easier to explain, even what they regard to be a fairly complicated and perhaps uninteresting topic, such as the history of learning in their vocation. One of the interviewed VTE students working as a teacher stated his VET students had enjoyed his presentation about the history of vocational learning; therefore, he had kept working with the theme: 'Since I never had this input myself when I went to upper secondary school, I have chosen to continue developing this [the presentation]' (Student interview 2). Another VTE student had recorded himself in a practical teaching situation to specifically look at how he could improve his teaching. The use of video has not only helped teachers focus on aspects that can be used for guiding teaching practice but has also inspired them to present a similar task when teaching or examining the VET students: 
I will be able to use this by asking a student, like: 'You will have to go to the process equipment room and describe how you calibrate a pressure transmitter, and a friend will film you. And then you send it in next Friday'. That could be a regular assignment, instead of giving them a written exam. (Student interview 2)

In conclusion, the VTE students' reflections are centred around a number of interlinked themes, such as creating a new discursive understanding of workknowledge and the teaching content, performing a strategic structuring of the content for sense-making, transcending the theory and practice divide through visual artefacts and practical tasks and forging the ability to use different teaching strategies.

\section{Trying to see through the VET students' eyes}

Many of the aspects concerning how VTE students reflect on the assignment and thus make meaning out of didactic ability can be related to how the use of video made them think about their performance. According to the students, the discussions in the seminar were focused around how the video sequence triggered thoughts about gestures, how they positioned themselves in front of the camera and how easy it was to hear what they were saying. The possibility to observe oneself led to a new experience and awareness of how it might be for the VET students:

Well, you become aware of, what shall I say...To see and to hear yourself is like, eh, it isn't really exactly the same as what you think. You become aware of your flaws. (Student interview 4)

The VTE students also argued that the video recordings of their peers served as a source of inspiration; by viewing the recordings, it became clear there were many different yet 'right' ways of presenting the content. The diversity and many different perspectives on the vocational learning history from their fellow students proved fascinating. In this respect, the seminar served as an arena for the exchange of experiences among the students. An important note, however, is that the students generally did not mention the seminar as a source for profound reflection on action, but rather focused on performance and gestures as dimensions of classroom practice.

A shared point among the VTE students was that the video recording helped them to see themselves from an outside perspective. By critically examining their teaching sequence, they got an understanding of the qualitative aspects of their interactions with the VET students, particularly how the students seemed to respond to the presented content:

Just the thing that you can look at yourself, from an outside perspective. Usually, you never really do that. It's really awful at first, when you see what you do, how you move and all that. You can also see the first graders, the students who participated, and how they understand what you are saying. (Student interview 1) 
By taking the perspective of a listener, the VTE students reflected on how explicit and articulated they were and that they sometimes took for granted that every student was following what was being addressed. It stands clear that video analysis helps to not only examine the teaching performance but also to notice that VET students might not follow and grasp the lesson content:

\begin{abstract}
I talk very fast, I do. I tend to expect that people will understand what I'm talking about, without having introduced them enough. That they should be expected to know what I'm thinking, you know. Now, I present in a much calmer way, more clearly, structured perhaps. (Student interview 4)
\end{abstract}

Besides the inclination to talk fast, the VTE student had realised the importance of being attentive to what the students know and their prior experiences before moving on to a new topic or theme. This, she believed, would improve teaching, help her to recast the content and make it tangible for the students.

The VTE students experienced challenges with video-recording and with uploading the movie on the learning management system. This made them feel uneasy. Some of them were a bit scared of how to record a teaching sequence for the first time, or as one answered in the interview: 'When I saw it [the assignment], my first thought was, oh no, I will never make this. I will never be able to work with digital media in such a way. But it wasn't that hard' (Student interview 1). To share and show the video-presentation in front of peers was generally not regarded as a problem. One of the VTE students thought the fellow students were probably 'just as nervous as I am', and in the interviews, the VTE students underlined that their peers were extremely important. The student group provided a supportive arena, not only for addressing technical problems but also for raising questions on teaching, how they should think regarding the structure and how the content on the history of vocational learning could be framed to engage the VET students.

\title{
Discussion
}

The VTE students' professional learning through the use of video

This study's findings strongly support observations from previous research regarding the use of video for forwarding and supporting teacher students' professional learning. For instance, the VTE students stated they develop a new understanding of how to organise content; they generate new meanings in recontextualising content for pedagogic practice (Bernstein, 2000), where video becomes a means to analytically handle the relationship between theoretical aspects and professional action (Barnhart \& van Es, 2015; Charalambous et al., 2018). Above 
all, the application of video and the construction of a lesson sequence are practical activities that are conducive for teacher student learning (Sylte \& Jahanlu, 2017; Syverstad \& Nymark, 2016).

One of the apparent qualities the VTE students ascribe to the use of video analysis for teaching practice development is the possibility to focus on and to critically and systematically examine their performance and actions over and over again. The video recording helps draw attention towards the complexity of teaching situations and allows the VTE students to address and articulate tacit dimensions (Marsh \& Mitchell, 2014). Tripp and Rich (2012) claim teachers who use video as part of professional development appreciate the possibilities to capture the progression in their learning, and they develop a readiness to change practice. Similar views could be observed in the answers from the VTE students. Furthermore, reflecting on the video sequence triggered thoughts about the interactions with students and how articulation, gestures and non-verbal communication could impede or promote VET student learning. The VTE students experienced a higher degree of attention towards how the VET students responded and how they themselves could improve teaching (Barnhart \& van Es, 2015; Stürmer et al., 2012). For example, the VTE students learned to be more attentive to the VET students' prior knowledge and experiences regarding the teaching content.

A related point to the notion of teaching improvement was that the VTE students expressed an increased awareness of different teaching strategies and that the student group served as an important arena for exchanging ideas and supporting their learning (Borko et al., 2008; Gaudin et al., 2014). In this case, the study also revealed some minor variations between the VTE students without previous teacher experience and the ones who worked as teachers. The former to a greater extent focused on video analysis as a good preparation for the period of teacher training placement, while the latter were more inclined to sources of inspiration. Even though there was a general agreement on the affordances of video, the noted difference underlines the importance of being aware of the individual learning trajectories of teacher students (Charalambous et al., 2018). However, the results regarding how the VTE students experienced the seminar (where they discussed their video analyses) show that practical and performative aspects were placed in the foreground; however, the reflections on action seemed to be somewhat superficial and shallow. This suggests the students were not equipped with strategies and tools for engaging in a deeper discussion and reflection on actions and practice (Calandra et al., 2008).

The analysis adds important insights on how the VTE students conceive the use of video for teaching vocational subjects and for promoting VET student learning. Video helped them reflect on vocational concepts as aspects of VET students' socialisation in vocational culture and identity. As has been discussed above, we could observe an appreciation of video for visualising tacit dimensions of action-based knowledge. Thus, we arrive at a similar conclusion to Broad 
(2016) and Nore (2015) regarding how the VTE students in our study described the importance of images and videos for visualising and transferring knowledge from the workplace context to the school context. The VTE students also believed that by using digital tools and other forms of media and representations in the VET students' 'digital world', it will be possible to encourage student activity and dialogue.

\section{Learner recontextualisation of didactic ability}

This article identifies a number of notions concerning how VTE students make meaning of didactic ability from the students' analyses of, and their reflections on, the video sequences. The following figure illustrates the notions of didactic ability in learner recontextualisation (Evans et al., 2009, 2010):

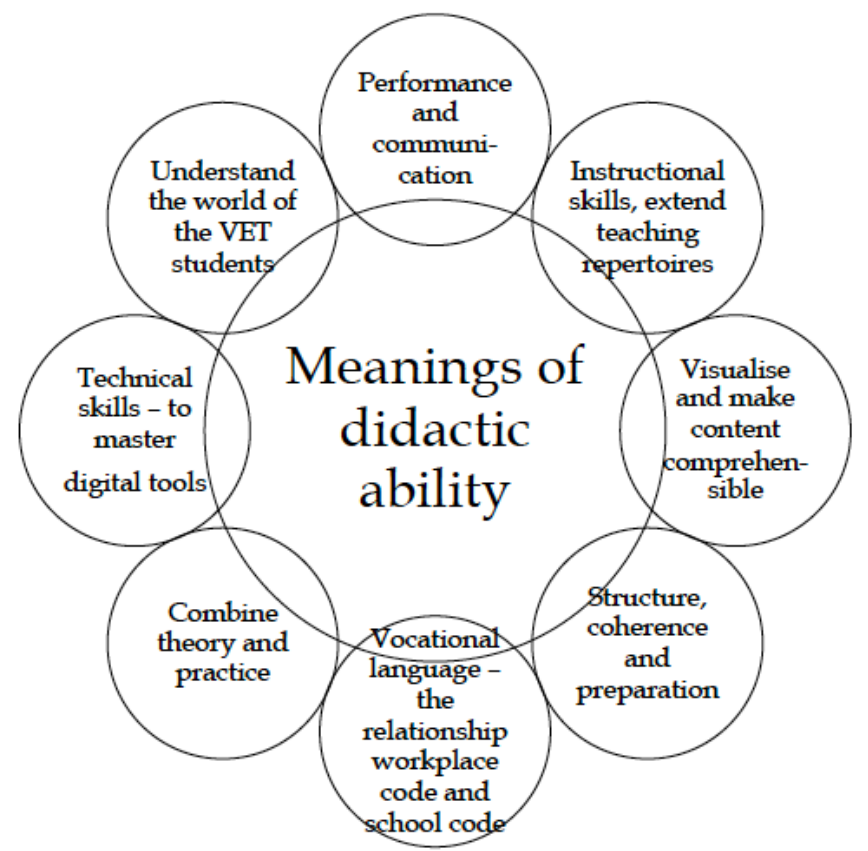

Figure 2. Emerging meanings of didactic ability in the VTE students' learner recontextualisation.

At first glance, the general aspects are closely linked to the organisation of teaching, the communicative repertoires in the classroom context and the didactic triad of teacher, student and content. When the VTE students engaged in what Evans et al. $(2009,2010)$ refer to as 'pedagogic recontextualisation', they had to reflect on how they should select and recast the historical content and how to structure and plan the teaching. Afterwards, they realised the importance of the performance and of communicating through voice and body-language. The meanings 
that emerged in the pedagogic discourse are focused around the teacher as a central actor in the classroom when it concerns the 'how' and the transmission of content for the VET students' acquisition of knowledge and the control over norms, values and mechanisms of identity-formation in the production of pedagogic discourse (Morais, 2002). It is also possible to identify the ability to master various repertoires for teaching or to use a 'toolbox' of strategies and methods such as digital tools - as parts of pedagogic discourse. This instrumental-technical dimension is linked to meanings that emphasise values of innovative, modern and interactive teaching.

VET teachers have vocational knowledge and experience acquired through education and work. They are members of the professional community of teachers but generally keep a strong sense of a vocational identity and a belonging to a particular vocational culture (Köpsén, 2014; Köpsén \& Andersson, 2015). The importance of vocational culture and identity, the workplace context and a specific knowledge base serves as a significant element in the VTE students' pedagogic discourse. Thus, a vocational discourse of vocational knowledge and workplace codes influences this culture and identity. By using the vocation's language and by working with sense-making of workplace concepts and codes, the VET students are given access to theoretical meaning systems of vocational knowledge (Wheelahan, 2015). Here, it is interesting to notice how language, actions, content, terminology and meanings in terms of workplace codes - inherent in the previous knowledge and experiences of the VTE students - tend to 'move' and be recontextualised from the school's pedagogic discourse.

This once again points at the significance of practical elements paired with critical reflection in VTE assignments (Sylte \& Jahanlu, 2017; Syverstad \& Nymark, 2016). Since video recordings can be shared, they provide possibilities for didactic reflection not only among teacher students but university teachers and in-service supervisors (Gelfuso \& Dennis, 2017). Universities can learn from research on introducing video-based assignments (Blomberg et al., 2013), and the analysis of how VTE students make meaning of didactic ability shows the potential to open a process-oriented and holistic perspective on the development of VTE through theory-based evaluation. This allows for dealing with the complexity of VTE in a structured and pro-active way, particularly in terms of the different 'codes' that operate within the pedagogic discourse and emerge in learner recontextualisation. By identifying, visualising and discussing these codes through the use of video analysis and systematic reflection, we can find new ways of supporting and promoting VTE students' professional learning.

\section{Notes on contributors}

Daniel Alvunger is Senior lecturer in Education. His main research interests are teachers' professional agency and curriculum making as social practice, and 
teacher education and teacher professionalism, with focus on the interplay between theory and practice in vocational teacher education.

Viktoria Grahn Johansson is PhD Student and chairman of the vocational teacher programme council. Her thesis project concerns the supervision and professional learning of vocational teacher students who already work as vocational teachers, while they are on teacher training placement in their own workplace. Both work at the Department of Education and Teachers' Practice, Linnæus University, Sweden. 


\section{References}

Alsawaie, O.N., \& Alghazo, I.M. (2010). The effect of video-based approach on prospective teachers' ability to analyze mathematics teaching. Journal of Mathematics Teacher Education, 13(3), 223-241.

Alvunger, D., \& Wahlström, N. (2017). Research-based teacher education? Exploring the meaning potentials of Swedish teacher education, Teachers and Teaching, 24(4), 332-349.

Alvunger, D., \& Adolfsson, C-H. (2016). Introducing a critical dialogical model for vocational teacher education. Nordic Journal of Vocational Education and Training, 6(1), 53-75.

Avis, J., Canning, R., Fisher, R., Morgan-Klein, B., \& Simmons, R. (2012). State intervention and teacher education for vocational educators in England and Scotland. Educational Research, 54(2), 187-197.

Barnhart, T., \& van Es, E. (2015). Studying teacher noticing: Examining the relationship among pre-service science teachers' ability to attend, analyze and respond to student thinking. Teaching and Teacher Education, 45, 83-93.

Bernstein, B. (2000). Pedagogy, symbolic control and identity: Theory, research, critique. Lanham, MD: Rowman \& Littlefield Publishers.

Blomberg, G., Renkl, A., Sherin, M.G., Borko, H., \& Seidel, T. (2013). Five research-based heuristics for using video in pre-service teacher education. Journal for Educational Research, 5(1), 90-114.

Borko, H., Jacobs, J., Eitelorg, E., \& Pittman, M.E. (2008). Video as a tool for fostering productive discussions in mathematics professional development. Teaching and Teacher Education, 24(2), 417-436.

Bound, H. (2011). Vocational education and training teacher professional development: tensions and context. Studies in Continuing Education, 33(2), 107-119.

Boutsioki, S. (2014). Policy transformations and institutional interventions regarding vet in an employment-oriented European Union. Review of European Studies, 6(1), 201-217.

Broad, J.H. (2016). Vocational knowledge in motion: Rethinking vocational knowledge through vocational teachers' professional development, Journal of Vocational Education \& Training, 68(2), 143-160.

Calandra, B., Gurvitch, R., \& Lund, J. (2008). An exploratory study of digital video editing as a tool for teacher preparation. Journal of Technology and Teacher Education, 16(2), 137-153.

Charalambous, C.Y., Philippou, S., \& Olympiou, G. (2018). Reconsidering the use of video clubs for student-teachers' learning during field placement: Lessons drawn from a longitudinal multiple case study. Teaching and Teacher Education $74,49-61$.

Cochran-Smith, M., \& Lytle, S.L. (1999). Relationships of knowledge and practice: Teacher learning in communities. Review of Research in Education, 24, 249-305. 
Cochran-Smith, M., \& Villegas, A.M. (2015). Framing teacher preparation research: An overview of the field, part 1. Journal of Teacher Education, 66(1), 720.

Creswell, J.W., \& Plano Clark, V. (2007). Designing and conducting mixed methods. London, England: SAGE.

Creswell, J.W. (2010). Mapping the developing landscape of mixed methods research. In A. Tashakkori, \& C. Teddlie (Eds.), Sage handbook of mixed methods in social $\mathcal{E}$ behavioral research (pp. 45-68). Thousand Oaks, CA: Sage Publications.

Darling-Hammond, L. (2008). Knowledge for teaching: What do we know? In M. Cochran-Smith, S. Feiman-Nemser, D.J. McIntyre, \& K.E. Demers, (Eds.), Handbook of research on teacher education. enduring questions in changing contexts (pp. 1316-1323). New York, NY: Routledge, Taylor \& Francis Group and The Association of Teacher Educators.

Darling-Hammond, L. (2006). Constructing 21st-century teacher education. Journal of Teacher Education, 57(3), 300-314.

Evans, K., Guile, D., \& Harris, J. (2009). Putting knowledge to work: Integrating workbased and subject-based knowledge in intermediate level qualifications and workforce upskilling. London, England: WLE Centre.

Evans, K., Guile, D., Harris, J., \& Allan, H. (2010). Putting knowledge to work: A new approach. Nurse Education Today, 30(3), 245-251.

Gaudin, C., Flandin, S., Ria, L., \& Chaliès, S. (2014). An exploratory study of the influence of video-viewing on preservice teachers' teaching activity: Normative versus developmental approaches. Form@re, 14(2), 21-50.

Gelfuso, A., \& Dennis, D.V. (2017). Video as text of teaching: Toward more deliberate literacy field experience supervision. The Teacher Educator, 52(1), 57-74.

Grollmann, P. (2008). The quality of vocational teachers: Teacher education, institutional roles and professional reality. European Educational Research Journal, 7(4), 535-547.

Kemmis, R.B., \& Green, A. (2013). Vocational education and training teachers' conceptions of their pedagogy. International Journal of Training Research, 11(2), 101-121.

Köpsén, S. (2014). How vocational teachers describe their vocational teacher identity. Journal of Vocational Education \& Training, 66(2), 194-211.

Köpsén, S., \& Andersson, P. (2015). Continuing professional development of vocational teachers: Participation in a Swedish national initiative. Empirical Research in Vocational Education and Training, 7(7), 1-20.

Marsh, B., \& Mitchell, N. (2014). The role of video in teacher professional development. Teacher Development, 18(3), 403-417.

Morais, A.M. (2002). Basil Bernstein at the micro level of the classroom. British Journal of Sociology of Education, 23(4), 559-569.

Moreno Herrera, L. (2016), Yrkesutbildningsutmaningar i nya tider: Vilken väg ska vi ta? Nordic Journal of Vocational Education and Training, 6(2), 66-83. 
Nore, H. (2015). Re-contextualizing vocational didactics in Norwegian vocational education and training. International Journal for Research in Vocational Education and Training, 2(3), 182-194.

Official Report. (2008). En hållbar lärarutbildning: Betänkande av Utredningen om en ny lärarutbildning (HUT 07) [A sustainable teacher education: Official report from the committee for a new teacher education (HUT 07)]. Stockholm, Sweden: Utbildningsdepartementet [Ministry of Education and Research].

Papier, J. (2010). From policy to curriculum in South African vocational teacher education: A comparative perspective. Journal of Vocational Education E Training, 62(2), 153-162.

Rauner, F, \& Maclean, R. (Eds.). (2008). Handbook of technical and vocational education and training research. Berlin, Germany: Springer.

Robertson, S., \& Dale, R. (2015). Towards a 'critical cultural political economy' account of the globalising of education. Globalisation, Societies and Education, 13(1), 149-170.

Singh, P., Thomas, S., \& Harris, J. (2013). Recontextualising policy discourses: A Bernsteinian perspective on policy interpretation, translation, enactment. Journal of Education Policy, 28(4), 465-480.

Stürmer, K., Könings, K.D., \& Seidel, T. (2012). Declarative knowledge and professional vision in teacher education: Effect of courses in teaching and learning. British Journal of Educational Psychology, 83(3), 467-483.

Sundberg, D. (2017). Mapping and tracing transnational curricula in classrooms: The mixed-methods approach. In N. Wahlström, \& D. Sundberg (Eds.), Transnational curriculum standards and classroom practices: The new meaning of teaching (pp. 48-65). New York, NY: Routledge.

Sylte, A.L., \& Jahanlu, D. (2017). Profesjonsrettet lærerutdanning for yrkesfag: Dagens undervisning og opplevelse av relevans. Scandinavian Journal of Vocations in Development, 2.

Syverstad, E., \& Nymark, S. (2016). Yrkesrelevante oppgaver i praktisk pedagogisk utdanning for yrkesfag. Scandinavian Journal of Vocations in Development, 1.

Tripp, T.R., \& Rich, P.J. (2012). The influence of video analysis on the process of teacher change. Teaching and Teacher Education, 28(5), 728-739.

Wahlström, N., \& Sundberg, D. (2015). Theory-based evaluation of the curriculum, Lgr11. Uppsala, Sweden: The Institute for Evaluation of Labour Market and Education Policy (IFAU).

Wallenborn, M. (2010). Vocational education and training and human capital development: Current practice and future options. European Journal of Education, 45(2), 181-198.

Wheelahan, L. (2015). Not just skills: What a focus on knowledge means for vocational education. Journal of Curriculum Studies, 47(6), 750-762. 